\title{
Foreign Participation in Life Insurance Markets: Evidence from OECD Countries
}

\author{
Dezhu Ye $\mathrm{e}^{\mathrm{a}, \mathrm{c}}$, Donghui $\mathrm{Li}^{\mathrm{b}}$, Zhian Chen ${ }^{\mathrm{a}}$, Fariborz Moshirian ${ }^{\mathrm{a}}$ and \\ Timothy Wee ${ }^{\mathrm{d}}$ \\ ${ }^{a}$ Department of Finance, Jinan University, Guangzhou 510632, China. \\ ${ }^{\mathrm{b}}$ School of Banking and Finance, University of New South Wales, Sydney, NSW 2052, Australia. \\ E-mail: Donghui@unsw.edu.au \\ ${ }^{\mathrm{c}}$ Research Institute of Finance, Jinan University, Guangzhou 510632, China. \\ ${ }^{\mathrm{d}}$ Equity Capital Markets, Citigroup Global Markets Asia Ltd, Hong Kong SAR.
}

This paper examines the determinants of foreign participation in life insurance markets across 24 OECD countries during the period 1993-2000. The empirical results show that socio-economic and market structure factors influence foreign participation in life insurance markets. More specifically, life expectancy, foreign market share, income, dependency ratio, financial development, level of competition, economic growth and market liberalisation have positive impacts, whereas expense/combined ratios and social security expenditure have negative impacts on foreign participation in life insurance markets. In addition, governance/legal indicators (common law, political stability, government effectiveness, regulatory quality, the rule of law and control of corruption) all show positive impacts on foreign participation in life insurance markets.

The Geneva Papers (2009) 34, 466-482. doi:10.1057/gpp.2009.9

Keywords: foreign life insurance; governance; regulation

\section{Introduction}

Foreign participation in domestic life insurance markets has greatly increased during the past decades, following the Uruguay Round international trade agreement and particularly the establishment of the WTO General Agreement on Trade in Services (GATS). Some regional deregulations have also facilitated greater foreign life insurer participation, such as the establishment of the third non-life and the third life directives by the Council of European Communities and the increased deregulations in some Asian financial markets, such as China. ${ }^{1}$ In the meantime, increased foreign competition and the resultant enhanced social welfare provide innovative and differentiated life insurance products to customers, which are more attractive, better priced and more suitable for consumer tastes. ${ }^{2}$ Foreign participation also benefits both participating insurance firms. For example, foreign insurers can achieve enlarged risk pooling based on larger geographical diversification. Local insurer risk capacity can be increased due to more capital, expertise and strategic benefits brought by foreign

\footnotetext{
${ }^{1}$ Sun (2003) examines the impact of WTO accession on China's insurance industry and concludes that foreign insurance companies may quickly build up presence with the removal of insurance business restrictions in China.

${ }^{2}$ Ma and Pope (2003), Li et al. (2007).
} 
insurers. As a consequence, this will bring benefits to the host country's overall economy, including increased financial stability, facilitation of trade and commerce, risk management, loss mitigation and more efficient capital allocation. ${ }^{3}$ Moreover, recent developments in bancassurance have also contributed to greater participation in the domestic life insurance sector by foreign banks, ${ }^{4}$ due to complementary features between life insurance and bank products, banking facilitation of the sale of life insurance products and potential synergies. ${ }^{5}$

Although substantial research has been conducted on international insurance services, this is the first paper to investigate foreign life insurer participation in light of the rapid deregulation, liberalisation and globalisation of the international life insurance industry. This paper has four significant contributions to current literature. First, this paper extends Li et al., ${ }^{6}$ examining the determinants of life insurance consumption in OECD countries to examine the determinants of foreign life insurance participation in domestic markets. In doing so, international factors are taken into account, such as market liberalisation, in addition to the demand factors documented by Li et al. ${ }^{7}$ Second, this paper develops an empirical model to investigate foreign life insurance participation vis-à-vis socio-economic and market structure factors. This paper has policy implications to encourage foreign participation and globalisation of international life insurance markets. In doing so, this paper complements the paper by Ma and Pope. ${ }^{8}$ Third, this paper documents the significant role of governance/legal factors played in foreign insurance markets, which supports previous literature on international life insurance consumption, ${ }^{9}$ international reinsurance $^{10}$ and on the location choice of the foreign affiliates of the largest insurance groups. ${ }^{11}$ Fourth, given that much of the motivation and consequences of international trade and investments in insurance services remain unclear, ${ }^{12}$ this paper sheds additional light on this issue.

The empirical results, based on a sample of 24 OECD countries during the period 1993-2000, show that socio-economic and market structure factors influence foreign participation in life insurance markets. More specifically, life expectancy (LE), foreign market share (MS), income (IN), dependency ratio (DR), financial development (FD), level of competition, economic growth and market liberalisation have positive impacts, whereas expense/combined ratios (ECRs) and social security (SS) expenditure have negative impacts on foreign participation in life insurance. In addition, governance/ legal indicators (common law, political stability (PS), government effectiveness (GE),

\footnotetext{
${ }^{3}$ Skipper and Klein (2000).

${ }^{4}$ According to Swiss Reinsurance Company, Sigma, (2002, 7: 5), bancassurance is defined, in its simplest form, as the distribution of insurance products by banks.

${ }^{5}$ Swiss Reinsurance Company, Sigma (2002) No. 7.

${ }^{6} \mathrm{Li}$ et al. (2007).

${ }^{7}$ Ibid.

${ }^{8} \mathrm{Ma}$ and Pope (2003).

${ }^{9}$ Ward and Zurbruegg (2002); Beck and Webb (2003).

${ }^{10}$ Cole et al. (2007).

11 Outreville (2008).

${ }^{12}$ See for example, Moshirian (1997 and 1999).
} 
regulatory quality (RQ), the rule of law (RL) and control of corruption (CR)) all show positive impacts on foreign participation in life insurance.

This study is structured as follows: the first section presents a review of the existing literature. The second section introduces factors influencing foreign participation in life insurer markets. The third section presents data and methodology. The fourth section provides empirical results and their implications, and then the paper concludes.

\section{Review of the existing literature}

Foreign participation in life insurance markets can be explained from various streams of literature including foreign direct investment (FDI) in insurance services, international trade in insurance services and demand for life insurance. FDI in insurance services is examined in some studies. For example, Moshirian ${ }^{13}$ concludes that the demand for insurance services as well as the size of the insurance sector of the source country, among other factors, significantly influences the level of FDI in insurance. Li and Moshirian ${ }^{14}$ analyse and discuss the determinants of FDI in insurance services in the United States. Their study shows that solid economic fundamentals in the host countries are the major factors that attract FDI in insurance services, although the uncertainty of the international exchange market increases the investment risk and reduces foreign investors' willingness to invest. More recently, Outreville ${ }^{15}$ examines the location-specific advantages for foreign affiliates of the largest insurance groups.

In addition, there are a few studies on international trade in insurance services. For example, Sapir and $\mathrm{Lutz}^{16}$ investigate the sources of comparative advantage in insurance services. Skipper ${ }^{17}$ analyses protectionism during international trade in insurance services. The $\mathrm{OECD}^{18}$ analyses the obstacles to foreign participation in domestic insurance markets, such as deposits or financial guarantees, business records in the home country and official certification of the supervisory authority in a home country. More recently, Li et al. ${ }^{19}$ analyse and measure the magnitude of intra-industry trade (IIT) in insurance services for the United States. They find that FDI in insurance services is a significant contributor to the volume of trade in insurance services.

Moreover, there are a few studies on demand for life insurance. For example, Campbell $^{20}$ argues that life insurance consumption is linked to lifetime uncertainty. Browne and $\mathrm{Kim}^{21}$ document that the following factors can influence a country's average life insurance consumption: the DR, national IN, government spending on SS, insurance price, inflation rate and religion. Outreville ${ }^{22}$ analyses life insurance markets in developing

\footnotetext{
${ }^{13}$ Moshirian (1997).

${ }^{14} \mathrm{Li}$ and Moshirian (2004)

15 Outreville (2008).

${ }^{16}$ Sapir and Lutz (1981).

${ }^{17}$ Skipper (1987).

18 OECD (1999).

${ }^{19} \mathrm{Li}$ et al. (2003).

${ }^{20}$ Campbell (1980).

${ }^{21}$ Browne and Kim (1993).

22 Outreville (1996).
} 
countries and documents a positive impact of FD and a negative impact of a monopolistic market on life insurance consumption, among other factors. More recently, Ward and Zurbruegg $^{23}$ investigate law, politics and life insurance consumption in Asia, and document the significance of legal/governance factors (RL, for instance) in determining life insurance consumptions in Asian and OECD countries. Beck and Webb ${ }^{24}$ investigate life insurance consumptions from 68 economies during the period 1961-2000, and document that economic, religious and institutional/governance indicators can explain the use of life insurance. Li et al., ${ }^{25}$ examine the determinants of life insurance consumption in OECD countries and conclude that life insurance demand is better explained when product market and socio-economic factors are jointly considered.

There are some papers on foreign participation in insurance markets. $\mathrm{Ma}$ and Pope $^{26}$ examine the importance of foreign market characteristics for the participation of international non-life insurers. Cole et $a l^{27}$ examine foreign reinsurance assumptions based on a sample of 35 reinsurers. Outreville ${ }^{28}$ examines the location choices of insurers to expand their operations. The purpose of this paper is to investigate foreign life insurer participation by including international factors, governance/legal factors and life insurance demand factors. To do so, several hypotheses are postulated based on socio-economic and market structure analysis.

\section{Factors influencing foreign participation in life insurance markets}

Li et $a l .^{29}$ document that location-specific variables, such as LE, SS expenditure, IN, $\mathrm{DR}$, anticipated inflation (AI), education, FD and foreign MS are significant in explaining the level of total life insurance demand in OECD countries. This paper builds upon that work by separating out total life insurance demand into domestic and foreign insurance companies. In doing so, international factors, such as market liberalisation, are also included to examine foreign participation. This could stem from the fact that foreign insurance companies price their products using a more diversified customer base across different countries. For instance, Ma and Pope ${ }^{30}$ document that market competition, market liberalisation, among others, are the factors influencing foreign participation in the non-life insurance market. This paper includes factors influencing demand for both life and non-life insurance products, such as education. In doing so, this paper explicitly controls for the impact of risk aversion on life insurance demand. Moreover, following recent literature development in this area, governance/legal factors are incorporated in this study. ${ }^{31,32}$

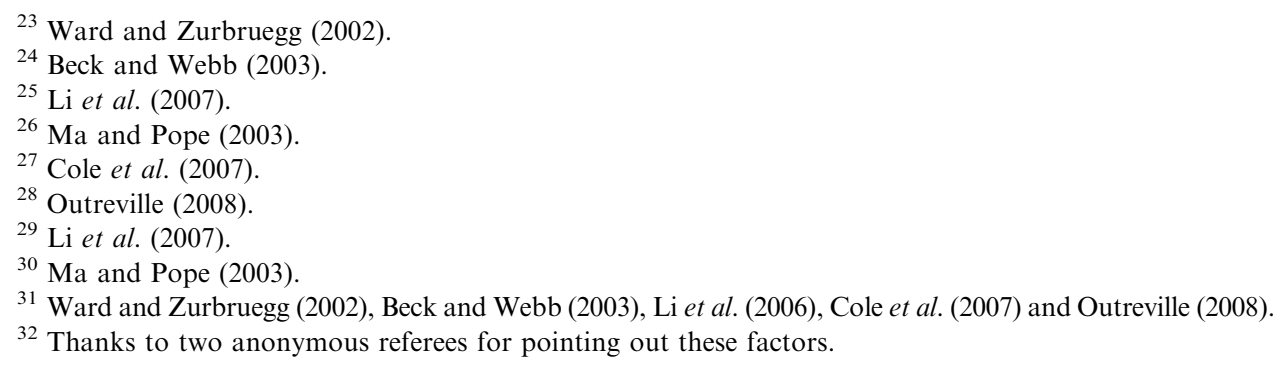


470

Consistent with Ma and Pope ${ }^{33}$ and Li et al. ${ }^{34}$ this paper uses premiums per capita in US\$ as a proxy for the level of foreign participation. The following 15 factors are hypothesised to influence how attractive a host country is to foreign life insurance providers.

\section{Socio-economic factors}

This section briefly outlines the socio-economic factors that influence the level of foreign participation in OECD countries, all of which are cited in previous literature on demand for life insurance.

(1) Anticipated Inflation (AI): The level of AI is expected to negatively influence life insurance consumption, including the level of foreign participation. ${ }^{35}$ This stems from the potential erosion effects on the consumption of life insurance products. ${ }^{36}$ Consistent with current literature, ${ }^{37} \mathrm{AI}$ is defined in this paper as the average inflation rate over the past 5 years.

(2) Average Life Expectancy ( $L E)$ : Ward and Zurbruegg ${ }^{38}$ document a positive impact, whereas Beck and Webb ${ }^{39}$ document a negative impact of LE on life insurance consumption across countries. It is hypothesised that the average LE of residents in the domestic country will affect the level of foreign participation, although the direction of this influence is not clear. A lower LE could lead to increases in the need for protection. ${ }^{40}$ However, should LE proxy the actuarially fair price of insurance, ${ }^{41}$ then a longer LE will reflect a lower price of insurance, and consequently a greater demand for life insurance.

(3) Income (IN): Current literature has established that IN can positively influence the level of life insurance demand. ${ }^{42}$ This literature documents the significance of DR in investigating life insurance consumption across countries for two reasons. First, the affordability of life insurance products is increased along with increased IN. Second, the expected loss for the dependants is greater in the event of the premature death of a higher IN earner. It is thus expected that IN will have a positive relationship with foreign participation levels, as greater life insurance demand will result in more incentives for foreign companies to enter a domestic market. In this study, per capita GDP in US\$ is used as a proxy for IN.

${ }^{33}$ Ma and Pope (2003).

${ }^{34} \mathrm{Li}$ et al. (2007).

${ }^{35}$ Fortune (1973); Cargill and Troxel (1979); Browne and Kim (1993); Outreville (1996); Ward and Zurbruegg (2002); Beck and Webb (2003).

${ }^{36}$ Fortune (1973).

${ }^{37}$ Outreville (1990,1996); Browne and Kim (1993).

${ }^{38}$ Ward and Zurbruegg (2002).

${ }^{39}$ Beck and Webb (2003).

${ }^{40}$ Browne and Kim (1993).

${ }^{41}$ Outreville (1996).

${ }^{42}$ Fortune (1973); Campbell (1980); Lewis (1989); Browne and Kim (1993); Outreville (1996); Ward and Zurbruegg (2002); Beck and Webb (2003). 
(4) Dependency Ratio ( $D R$ ): Dependants can be protected financially by life insurance if the wage earner dies prematurely. ${ }^{43}$ Truett and Truett, ${ }^{44}$ and Browne and Kim, ${ }^{45}$ document a positive relation between DR and life insurance consumption. Ward and Zurbruegg, ${ }^{46}$ and Beck and $\mathrm{Webb}^{47}$ document the significance of DR in investigating life insurance consumption across countries. This paper hypothesises that foreign life insurance participation is positively related to the DR, where the DR is taken as the ratio of the population under 15 and over 64 to the working class population aged between 15 and 64 years.

(5) Social Security expenditure (SS): The impact of SS expenditure on foreign participation is unclear. Following Lewis; ${ }^{48}$ Browne and Kim $;{ }^{49}$ and Skipper and Klein, ${ }^{50} \mathrm{SS}$ expenditure could substitute for insurance arising from better protection in wealthier countries, which results in a negative impact. On the other hand, SS expenditure could only be available upon the survival of wage earners, thus giving rise to a greater need for life insurance in wealthier countries. ${ }^{51}$ This results in a positive impact. To measure SS expenditure, per capita public social expenditure in US\$ is used.

(6) Human Capital (EDU): A higher level of education in a country's population reflects greater risk aversion, which results in an increased awareness of the need for protection through life insurance. ${ }^{52}$ In addition, higher education lengthens children dependency. ${ }^{53}$ Thus, education is expected to have a positive relationship with foreign insurers' life insurance consumption and is measured by the level of tertiary education. (7) Economic growth $(G R O W)$ : It is assumed that higher economic growth leads to higher demand for foreign life insurance. This stems from higher levels of risk involved in a scenario of increasingly interactive individuals in rapidly growing economies. Outreville $^{54}$ includes economic growth in his analysis of the factors influencing the location choice of the foreign affiliates of the largest insurance groups.

\section{Market structure factors}

In addition to the above socio-economic factors, this paper incorporates market structure factors to investigate foreign participation in domestic life insurance markets, such as foreign MS, the level of FD, market liberalisation and level of competition.

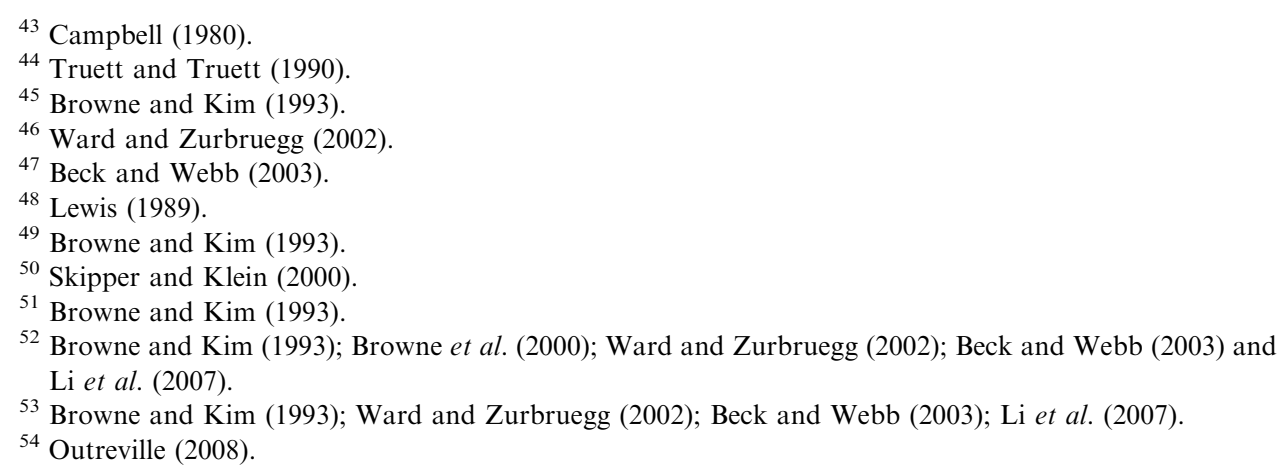


(1) Foreign participants' Market Share (MS): This paper hypothesises that foreign MS can have a positive impact on foreign participation for two reasons. First, foreign MS represents openness in the domestic economy. Foreign participation is thus expected to be higher in a more open economy with higher foreign MS. For example, Li et al. ${ }^{55}$ show that market openness can influence the U.S. IIT in insurance services. Second, foreign participation may be discouraged when facing a highly competitive internal insurance market. Thus, a lower foreign MS could be associated with lower foreign participation. ${ }^{56}$ On the other hand, it is hypothesised in this paper that if foreign MS represents the market position of foreign participants, it should have a negative impact on domestic competitors. This is consistent with Outreville ${ }^{57}$ and $\mathrm{Li}$ et al., ${ }^{58}$ who documented a negative relation between foreign MS and life insurance assumptions in domestic markets, though the relation in Outreville ${ }^{59}$ is insignificant. In this paper, foreign MS is defined as the MS of foreign-controlled undertakings and branches and agencies of foreign undertakings compared with total domestic business on a gross premiums basis.

(2) Financial Development (FD): The level of FD can positively influence the level of foreign participation. More developed financial markets are associated with higher transparency in regulatory and reporting requirements and better corporate governance practice, thus attracting more foreign participation. Furthermore, a more developed financial market indicates greater opportunity for foreign life insurers, such as easier financing and larger product markets. Outreville ${ }^{60}$ establishes the importance of FD to insurance consumption. Li and Moshirian ${ }^{61}$ show that FD can influence FDI decisions in the U.S. insurance industry. This paper uses the ratio of M2 to GDP as the proxy for FD, consistent with Outreville. ${ }^{62}$

(3) Market Liberalisation (international business climate (IBC)): The level of market liberalisation represents the barriers related to international trade in insurance services. Following Ma and Pope, ${ }^{63}$ this paper uses the IBC index devised by the Political Risk Services Group as a measure of market liberalisation. The level of liberalisation of a country is gauged on a scale of 0 to 100 , where a score of 100 denotes the most favourable climate for foreign traders. IBC is expected to have a positive impact on foreign participation since countries with lower barriers to trade and a more liberalised environment will tend to attract more foreign insurers.

(4) Level of competition (Herfindahl index (HI)): In addition to the market liberalisation, this paper also incorporates a variable that accounts for the level of competition in the market. $\mathrm{Ma}$ and $\mathrm{Pope}^{64}$ find that a more competitive non-life

\footnotetext{
${ }^{55} \mathrm{Li}$ et al. (2003).

56 Browne et al. (2000).

${ }^{57}$ Outreville (1996).

${ }^{58} \mathrm{Li}$ et al. (2007).

59 Outreville (1996).

${ }^{60}$ Outreville $(1990,1996)$.

${ }^{61}$ Moshirian (1997).

62 Outreville $(1990,1996)$.

${ }^{63} \mathrm{Ma}$ and Pope (2003).

${ }^{64} \mathrm{Ma}$ and Pope (2003).
} 
insurance market results in greater foreign insurers' premium levels. This paper hypothesises that for life insurance markets, though a more competitive market with an efficient business and regulatory environment will lead to a greater level of foreign participation, a more non-competitive market with monopolies may also increase the demand for foreign life insurance products, if the foreign life insurance products are differentiated from the insurance products provided by domestic insurers. ${ }^{65}$ The $\mathrm{HI}^{66}$ is used to measure the level of competition. In this paper, following the National Association of Insurance Commissioners' (NAIC) criteria for defining a competitive marketplace, HI measurements greater than 1,800 are classified as non-competitive and a dummy value of 1 is assigned. It is hypothesised that there is a positive/negative relationship between the HI and foreign participation levels.

(5) Expense Combined Ratios (ECRS): These two ratios ${ }^{67}$ represent the profitability potential of the foreign life insurers' operation in these countries. ${ }^{68}$ According to $\mathrm{Ma}$ and Pope, ${ }^{69}$ a lower loss ratio, representing higher profitability, attracts more foreign life insurers' participation. Thus, it is expected that there is a negative relationship between these two ratios and the demand for foreign life insurance.

\section{Governance/legal factors}

(1) Common law (LT): In this paper, common law country is used as a dummy variable to indicate different legal origins. La Porta et al. ${ }^{70}$ argue that common law countries have better investor protection in share markets compared with civil law countries. Li et al. ${ }^{71}$ have documented that governance/legal factors can influence insurance companies' decisions to become large shareholders in the stock markets. It is thus assumed in this paper that a common law legal environment has a positive impact on the demand for foreign life insurance.

(2) Governance indicators $(G O V)$ : Ward and Zurbruegg, ${ }^{72}$ and Beck and $\mathrm{Webb}^{73}$ show that legal/governance factors influence life insurance consumption across countries. Cole et al. ${ }^{74}$ have shown that governance factors can influence foreign reinsurance assumptions on the basis of 35 reinsurers. Outreville ${ }^{75}$ shows that good corporate governance has a strong impact on the choice of foreign affiliate countries by the world's largest financial groups. Outreville ${ }^{76}$ has documented that governance factors can influence the choice of foreign affiliates' location by the largest insurance groups.

\footnotetext{
${ }^{65}$ Li et al. (2003).

${ }^{66}$ Summing the squared market shares of individual insurers in each country and multiplying the result by 10,000 calculate the HI. For a perfectly monopolistic market, the HI obtained would be 10,000.

${ }^{67}$ Thanks to an anonymous referee for pointing this out.

${ }^{68} \mathrm{Ma}$ and Pope (2003).

69 Ibid.

${ }^{70}$ La Porta et al. (1998).

${ }^{71} \mathrm{Li}$ et al. (2006).

${ }^{72}$ Ward and Zurbruegg (2002).

${ }^{73}$ Beck and Webb (2003).

${ }^{74}$ Cole et al. (2007).

75 Outreville (2007).

${ }^{76}$ Outreville (2008).
} 
It is thus assumed in this paper that a good local governance environment has a positive impact on the demand for foreign life insurance. Six country governance factors (voice and accountability (VA), political stability (PS), government effectivenss (GE), regulatory quality (RQ), rule of law (RL) and control of corruption (CR)) are used to proxy for governance quality in one particular host country.

\section{Data and methodology}

Cross-sectional data from 1993 to 2000 for the following 24 OECD countries are used in this study: Australia, Austria, Belgium, Canada, Denmark, Finland, France, Germany, Hungary, Iceland, Ireland, Japan, Korea, Luxembourg, Mexico, the Netherlands, Norway, Poland, Portugal, Spain, Switzerland, Turkey, the United Kingdom and the United States. ${ }^{77}$

The IBC rating is obtained from the Country Forecasts ${ }^{78}$ publication from the Political Risk Services (various issues). Individual insurers' Market Shares are obtained from Axco Insurance Information Services. Data for total foreign premiums are from the OECD's (2002a) Insurance Statistical Yearbook. Inflation rates, shortterm interest rates and M2 are from the IMF's International Financial Statistics CD-ROM. Population is from the OECD's (2003) Economic Outlook: Annual and Semi-annual data. Education level, as a proxy for human capital endowment, is from the UNESCO Statistical Yearbook (various issues). SS is from OECD's (2001) Public Expenditure. Average LE is from the IMD's (various issues) World Competitiveness Yearbook. GDP and exchange rates are in nominal terms and from the OECD's (2002b) Annual National Accounts - Volume I - Main Aggregates. For consistency, GDP data is on a per capita basis and are expressed in US\$. The exchange rates for countries that switched to the euro in 1999 are adjusted using the fixed exchange rate between the euro and the domestic currency as obtained from the European Central Bank. Legal origin data are from La Porta et al. ${ }^{79}$ Six government governance indicators are from Kaufmann et al. ${ }^{80}$

The empirical model to be tested is as follows:

$$
\begin{aligned}
L O G(F O R T)= & \beta_{0}+\beta_{1}(A I)+\beta_{2} L O G(L E)+\beta_{3} L O G(M S)+\beta_{4} L O G(I N) \\
& +\beta_{5} L O G(D R)+\beta_{6} L O G(S S)+\beta_{7} L O G(E D U)+\beta_{8} L O G(F D) \\
& +\beta_{9} G R O W+\beta_{10} H I+\beta_{11} I B C+\beta_{12} L T+\beta_{13} F T G E \\
& +\beta_{14} E C R+\beta_{15} G O V+\varepsilon_{1}
\end{aligned}
$$

The above Eq. (1) is estimated by pooled least squares. We also tried fixed and random effect panel methods. Hausman tests show that the fixed effect panel model is

\footnotetext{
${ }^{77}$ Countries excluded due to missing foreign market share data include Greece, Italy, New Zealand and Sweden. Missing inflation data lead to the exclusion of the Czech and Slovak Republics in our sample.

${ }^{78}$ Country Forecasts (2001).

${ }^{79}$ La Porta et al. (1998).

${ }^{80}$ Kaufmann et al. (2003).
} 
Table 1 Descriptive statistics

\begin{tabular}{|c|c|c|c|c|c|c|c|}
\hline Variable & Mean & Median & Maximum & Minimum & s.d. & Skewness & Kurtosis \\
\hline Foreign participation (FORT) & 1.67 & 1.83 & 3.97 & -0.9 & 0.96 & -0.41 & 3.59 \\
\hline Anticipated inflation (AI) & 0.63 & 0.47 & 2.29 & -0.39 & 0.5 & 1.34 & 4.51 \\
\hline Life expectancy (LE) & 1.88 & 1.89 & 1.9 & 1.84 & 0.02 & -1.27 & 3.75 \\
\hline Foreign market share (MS) & 1.03 & 1.12 & 2 & -0.47 & 0.6 & -0.47 & 2.43 \\
\hline Income (IN) & 4.2 & 4.35 & 4.64 & 2.35 & 0.41 & -1.81 & 6.45 \\
\hline Dependency ratio (DR) & -0.29 & -0.3 & 0.29 & -0.5 & 0.13 & 3.34 & 15.82 \\
\hline Social security (SS) & 3.88 & 3.91 & 5.73 & -0.76 & 1.3 & -1.46 & 6.66 \\
\hline Human capital (EDU) & 1.63 & 1.68 & 1.95 & 0.96 & 0.22 & -1.3 & 4.32 \\
\hline Financial development (FD) & -0.16 & -0.17 & 0.56 & -0.69 & 0.22 & 0.94 & 5.21 \\
\hline GDP growth (GROW) & 3.51 & 3.40 & 11.50 & -6.70 & 2.70 & -0.19 & 5.20 \\
\hline Herfindahl index (HI) & 0.17 & 0 & 1 & 0 & 0.37 & 1.79 & 4.2 \\
\hline IBC rating (IBC) & 87.05 & 88 & 100 & 65 & 7.83 & -0.77 & 3.22 \\
\hline $\begin{array}{l}\text { Free trade dummy* government } \\
\text { Effectiveness (FTVGE) }\end{array}$ & 1.02 & 1.41 & 2.52 & -0.22 & 0.82 & -0.18 & 1.44 \\
\hline Expense ratio (ER) & 0.48 & -0.07 & 5.77 & -1.37 & 1.49 & 1.83 & 6.21 \\
\hline Expense/combined ratio (ECR) & -1.7 & -1.17 & -0.23 & -6.5 & 1.37 & -2.07 & 6.79 \\
\hline Life premium/life in force (LP) & -1.19 & -0.55 & 0.28 & -4.46 & 1.64 & -0.53 & 1.86 \\
\hline Government effectiveness (GE) & 1.39 & 1.55 & 2.52 & -0.34 & 0.65 & -0.9 & 3.07 \\
\hline Voice and accountability (VA) & 1.2 & 1.37 & 1.67 & -0.92 & 0.53 & -2.24 & 7.63 \\
\hline Political stability (PS) & 0.97 & 1.12 & 1.77 & -1.06 & 0.6 & -1.87 & 6.48 \\
\hline Rule of law (RL) & 1.48 & 1.75 & 2.36 & -0.38 & 0.65 & -1.29 & 3.68 \\
\hline Control of corruption (CR) & 1.47 & 1.68 & 2.58 & -0.46 & 0.77 & -0.83 & 2.8 \\
\hline Regulatory quality (RQ) & 1.08 & 1.18 & 1.87 & 0.24 & 0.38 & -0.51 & 2.3 \\
\hline
\end{tabular}

"Mean" is the average value of the variables of column 1. "Median" is the middle value of the variables of column 1. "Maximum" is the highest value of the variables of the column 1. "Minimum" is the lowest value of the variables of the column 1. "s.d." is the square root of the variance of the variables of the column 1 . "Skewness" is the measure of oblique asymmetry of the variables of the column 1. "Kurtosis" is the measure of whether the statistical distribution of the variables of the column 1 is peaked or flat, relative to a normal distribution.

more feasible than the random effect panel model. In the fixed effect panel model, empirical results are qualitatively similar to those from pooled least squares. Thus, only the empirical results from the latter are reported in this paper and the empirical results from the former are available upon request from authors.

Table 1 presents the descriptive statistics for the variables used in this paper.

\section{Empirical results}

Table 2 presents the empirical results. There is a significantly positive impact of LE on foreign participation. It could reflect the offsetting consequence of these two opposite effects: a lower LE could lead to increases in the need for protection, ${ }^{81}$ however should

\footnotetext{
${ }^{81}$ Browne and Kim (1993).
} 


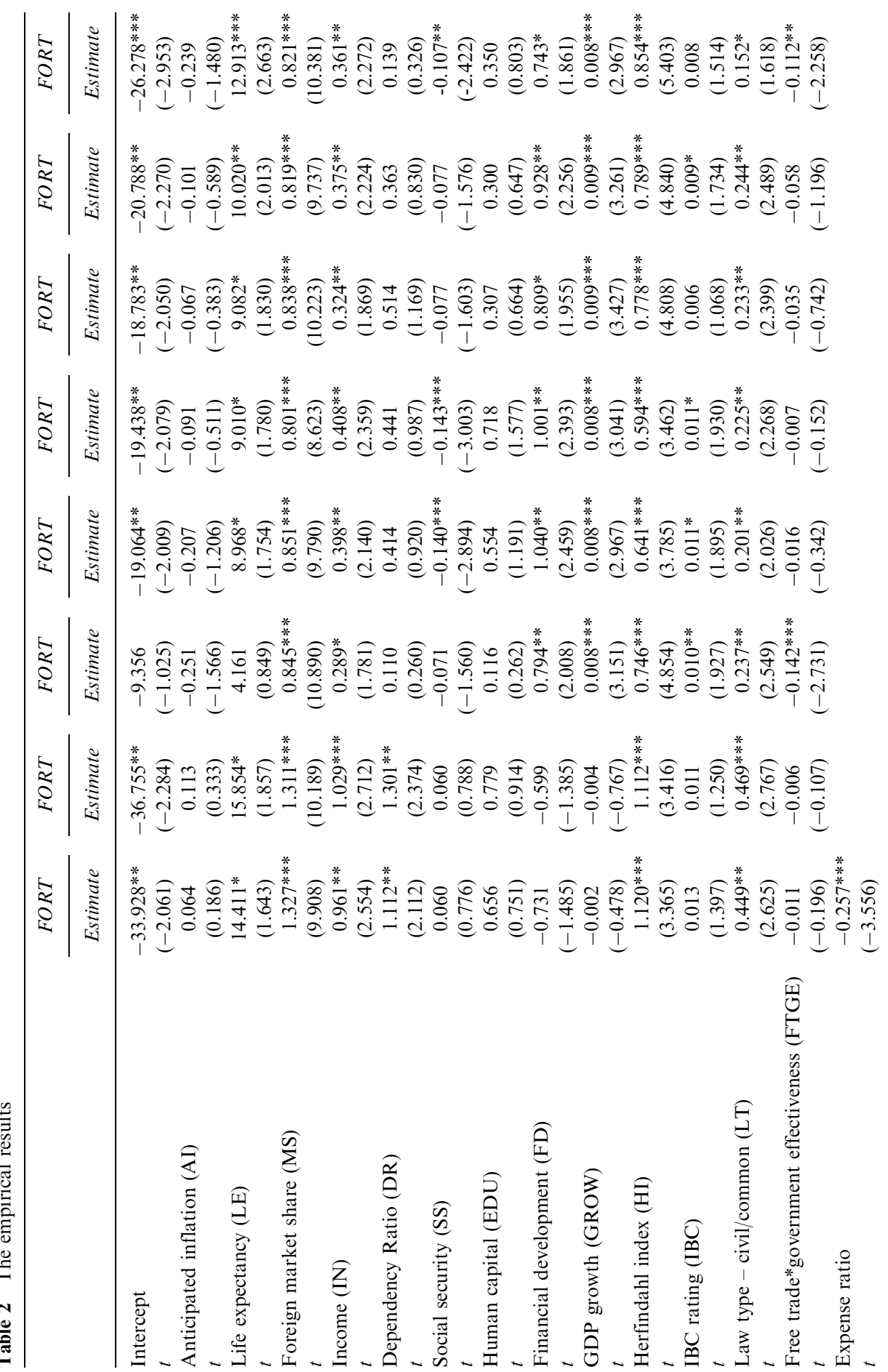




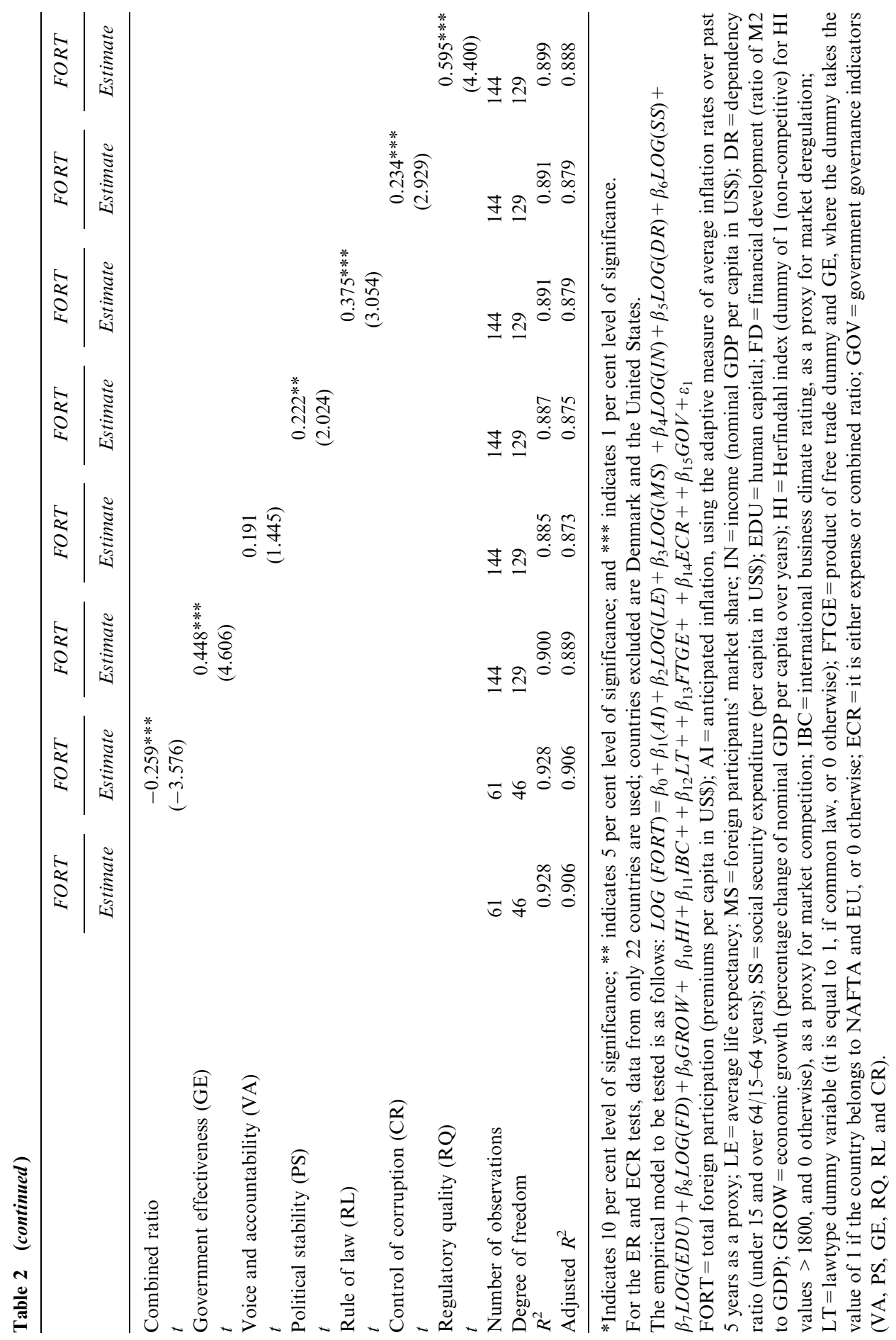


LE proxy the actuarially fair price of insurance; ${ }^{82}$ a longer LE will reflect a lower price of insurance, and consequently a greater demand for life insurance. It suggests that the positive effect of the latter dominates the negative effect of the former. The positive effect is consistent with Ward and Zurbruegg. ${ }^{83}$

Foreign participants' MS has a positive impact on foreign participation. First, foreign participation is expected to be higher in a more open economy with higher foreign MS. Secondly, foreign participation is lower when facing an internally highly competitive insurance market, represented by a lower foreign MS. This is consistent with Li et al., ${ }^{84}$ but in contrast to Outreville ${ }^{85}$ and Li et al., ${ }^{86}$ who document a negative relation between foreign MS and life insurance assumptions in domestic markets, although the relation in Outreville ${ }^{87}$ is insignificant.

As expected, IN has positively influenced the level of life insurance demand, which is consistent with Browne and Kim; ${ }^{88}$ Outreville; ${ }^{89}$ Ward and Zurbruegg, ${ }^{90}$ Beck and Webb; ${ }^{91}$ and $\mathrm{Li}$ et al. ${ }^{92}$ There are two reasons for this positive impact. First, the affordability of life insurance products is increased along with increased IN. Second, the expected loss for the dependants is greater in the event of premature death of a higher IN earner.

It has been found that DR has a positive impact on foreign participation. This is due to the function of life insurance to protect dependants financially if the wage earner dies prematurely, which is consistent with Truett and Truett; ${ }^{93}$ Browne and Kim; ${ }^{94}$ and Li et al. ${ }^{95}$

The impact of SS expenditure is significantly negative on foreign participation. This confirms the studies by Lewis; ${ }^{96}$ Browne and Kim $;{ }^{97}$ and Skipper and Klein, ${ }^{98}$ which state that SS expenditure could substitute for insurance arising from better protection in wealthier countries.

FD, as expected, has a positive impact on foreign participation. More developed financial markets are associated with higher transparency in regulatory and reporting requirements and better corporate governance practice, thus attracting more foreign and domestic participation. Further, a more developed financial market indicates greater opportunity for both domestic and foreign life insurers, such as easier

\footnotetext{
${ }^{82}$ Outreville (1996).

${ }^{83}$ Ward and Zurbruegg (2002).

${ }^{84} \mathrm{Li}$ et al. (2003).

${ }^{85}$ Outreville (1996).

${ }^{86} \mathrm{Li}$ et al. (2007).

${ }^{87}$ Outreville (1996).

${ }^{88}$ Browne and Kim (1993).

${ }^{89}$ Outreville (1996).

${ }^{90}$ Ward and Zurbruegg (2002).

${ }^{91}$ Beck and Webb (2003).

${ }^{92} \mathrm{Li}$ et al. (2007).

93 Truett and Truett (1990).

${ }^{94}$ Browne and Kim (1993).

${ }^{95} \mathrm{Li}$ et al. (2007).

96 Lewis (1989).

${ }^{97}$ Browne and Kim (1993).

${ }^{98}$ Skipper and Klein (2000).
} 
financing and larger product markets. This result is consistent with Outreville; ${ }^{99}$ Li and Moshirian; ${ }^{100}$ and Li et al. ${ }^{101}$

As expected, economic growth has been found to positively influence the demand for foreign life insurance. There are more risks involved in increasingly interactive individuals in rapidly growing economies, and thus, there is more demand for differentiated foreign life insurance products.

Market liberalisation (IBC) has a significantly positive impact on foreign participation. This shows that countries with lower barriers to trade and a more liberalised environment will tend to attract more foreign insurers. This is consistent with the argument in Ma and Pope. ${ }^{102}$

Common law countries (LT), as expected, have a positive impact on foreign participation. This is consistent with La Porta et al. ${ }^{103}$ who document that common law countries have better investor protection for shareholders than civil law countries.

Level of competition (HI) has a positive impact on foreign participation. This shows that a greater demand for differentiated foreign insurance products exists whether this host market is competitive or not. This result is in contrast with Ma and Pope.

As expected, both expense and combined ratios have negative impacts on the demand for foreign life insurance. This is consistent with Ma and Pope ${ }^{104}$ who argue that foreign insurers are more attractive to lower ECRs, which represent higher profitability.

As expected, governance/legal factors have a positive impact on the demand for foreign life insurance, which is consistent with the findings of Ward and Zurbruegg; ${ }^{105}$ Beck and Webb; ${ }^{106}$ Cole et al. ${ }^{107}$ and Outreville. ${ }^{108}$ More specifically, five out of six government governance indicators (political stability, government effectiveness, regulatory quality, the rule of law and control of corruption) all exhibit positive and of significant impacts on the demand for foreign life insurance. The sixth factor, voice and accountability, also exhibits a positive, though not significant, impact.

The interaction item between free trade and government effectiveness shows an unexpected negative impact on the demand for foreign life insurance. One of the most important features for life insurance products is locality proximity. In other words, customers tend to demand the life insurance products provided by local life insurers for reasons of information advantage and the long-term nature of this demand. So even if a free trade agreement exists, and government is effective, the insured may still tend to demand more products from local life insurers, which results in negative demand for foreign life insurers.

\footnotetext{
${ }^{99}$ Outreville (1996).

${ }^{100} \mathrm{Li}$ and Moshirian (2004).

101 Li et al. (2007).

$102 \mathrm{Ma}$ and Pope (2003).

${ }^{103}$ La Porta et al. (1998).

${ }^{104} \mathrm{Ma}$ and Pope (2003).

105 Ward and Zurbruegg (2002).

106 Beck and Webb (2003).

${ }^{107}$ Cole et al. (2007).

108 Outreville (2008).
} 
Finally, it has been found that two factors (anticipated inflation (AI) and education (HI)) have the expected signs, though not significant.

\section{Conclusion}

Foreign participation in domestic life insurance markets has greatly increased due to deregulation, liberalisation and globalisation of the international life insurance market. In the meantime, increased foreign competition and the resultant enhanced social welfare provide customers with innovative and differentiated life insurance products to customers, which are more attractive, better priced and more suitable for consumer tastes. ${ }^{109}$

This paper contributes to current literature by Ma and Pope, ${ }^{110} \mathrm{Li}$ et al., ${ }^{11}$ Cole et $a .^{112}$ and Outreville, ${ }^{113}$ and sheds additional light on international trade and international investment in insurance services. The empirical results show that socio-economic and market structure factors can influence foreign participation in life insurance markets. In addition, governance/legal indicators (common law, political stability, government effectiveness, regulatory quality, the rule of law and control of corruption) all show a positive impact on foreign participation in life insurance.

There are policy implications. Foreign participation should be encouraged by policy-makers, as it will benefit the host country's overall economy through increased financial stability, facilitation of trade and commerce, risk management, loss mitigation and more efficient capital allocation. In addition, policies for international trade in insurance services should be orientated more towards deregulation, liberalisation and globalisation.

\section{Acknowledgements}

Timothy Wee acknowledges the help from Associate Professors Toan Pham and Ah-Boon Sim from the University of New South Wales. Donghui Li acknowledges the financial support from the Natural Science Foundation of China (Fund no. 70831004).

\section{References}

Beck, T. and Webb, I. (2003) 'Economic, demographic, and institutional determinants of life insurance consumption across countries', World Economic Review 17: 51-88.

Browne, M.J. and Kim, K. (1993) 'An international analysis of life insurance demand', Journal of Risk and Insurance 60: 616-634.

Browne, M.J., Chung, J. and Frees, E.W. (2000) 'International property - Liability insurance consumption', Journal of Risk and Insurance 67: 73-90.

Campbell, R.A. (1980) 'The demand for life insurance: An application of the economics of uncertainty', Journal of Finance 35: 1155-1172.

\footnotetext{
${ }^{109} \mathrm{Ma}$ and Pope (2003), Li et al. (2003).

${ }^{110} \mathrm{Ma}$ and Pope (2003).

111 Li et al. (2007).

112 Cole et al. (2007).

113 Outreville (2008).
} 
Cargill, T.F. and Troxel, T.E. (1979) 'Modeling life insurance savings: Some methodological issues', Journal of Risk and Insurance 46: 391-410.

Cole, R., Lee, R. and McCullough, K. (2007) 'A test of the eclectic paradigm: Evidence from the US reinsurance market', Journal of Risk and Insurance 74: 493-522.

Country Forecasts (2001), The Economist Intelligence Unit, www.eiv.com (accessed 19 May 2001).

Fortune, P. (1973) 'A theory of optimal life insurance: Development and tests', Journal of Finance 27: 587-600.

IMD. World Competitiveness Yearbook (1994-2002), Lausanne, Switzerland: International Institute for Management Development, various issues.

Kaufmann, D., Kraay, A. and Mastruzzi, M. (2003) Governance matters III: Governance indicators for 1996-2002, World Bank Policy Research Working Paper 3106, World Bank.

La Porta, R., Lopez-de-Silanes, F., Shleifer, A. and Vishny, R. (1998) 'Law and finance', Journal of Political Economy 106: 1115-1155.

Lewis, F.D. (1989) 'Dependents and the demand for life insurance', American Economic Review 79: 452-467.

Li, D. and Moshirian, F. (2004) 'International investment in insurance services in the US', Journal of Multinational Financial Management 14: 249-260.

Li, D., Moshirian, F. and Sim, A.B. (2003) 'The determinants of intra-industry trade in insurance services', Journal of Risk and Insurance 70: 269-287.

Li, D., Moshirian, F., Pham, P. and Zein, J. (2006) 'When financial institutions are large shareholders - The role of macro corporate governance environments', Journal of Finance 61: 2975-3007.

Li, D., Moshirian, F., Nguyen, P. and Wee, T. (2007) 'The demand for life insurance in OECD countries', Journal of Risk and Insurance 74: 637-652.

Ma, Y.L. and Pope, N. (2003) 'Determinants of international insurers' participation in foreign non-life markets', Journal of Risk and Insurance 70: 235-248.

Moshirian, F. (1997) 'Foreign direct investment in insurance services in the United States', Journal of Multinational Financial Management 7: 159-173.

Moshirian, F. (1999) 'Sources of growth in international insurance services', Journal of Multinational Financial Management 9: 177-194.

OECD (1999) Liberalisation of International Insurance Operations. Cross-Border Trade and Establishment of Foreign Branches, Organization for Economic Cooperation and Development, Paris, France.

OECD (2001) Public Expenditure, Vol 2001, release 01, Organization for Economic Cooperation and Development, www.sourceoecd.com, Paris, France.

OECD (2002a) Insurance Statistical Yearbook, Vol 2002, release 01, Organization for Economic Cooperation and Development, www.sourceoecd.com.

OECD (2002b) Annual National Accounts - Volume I - Main aggregates, Vol 2002, release 04, Organization for Economic Cooperation and Development, www.sourceoecd.com, Paris, France.

OECD (2003) Economic Outlook: Annual and Semi-annual data, Vol 2003, release 01, Organization for Economic Cooperation and Development, www.sourceoecd.com, Paris, France.

Outreville, J.F. (1990) 'The economic significance of insurance markets in developing countries', Journal of Risk and Insurance 57: 487-498.

Outreville, J.F. (1996) 'Life insurance markets in developing countries', Journal of Risk and Insurance 63: $263-278$.

Outreville, J.F. (2007) 'Foreign affiliates of the world largest financial groups: Locations and governance', Research in International Business and Finance 21: 19-31.

Outreville, J.F. (2008) 'Foreign affiliates of the largest insurance groups: Location-specific advantages', Journal of Risk and Insurance 75: 463-491.

Sapir, A. and Lutz, E. (1981) Trade in services: Economic determinants and development-related issues, World Bank Staff Working Paper no. 410, World Bank.

Skipper, H.D. (1987) 'Protectionism in the provision of international insurance services', Journal of Risk and Insurance 54: 55-85.

Skipper, H.D. and Klein, R.W. (2000) 'Insurance regulation in the public interest: The path towards solvent, competitive markets', The Geneva Papers on Risk and Insurance - Issues and Practice 25(4): 482-504. 
Sun, Q. (2003) 'The impact of WTO accession on China's insurance industry', Risk Management and Insurance Review 6: 27-35.

Swiss Reinsurance Company (2002) Sigma, (various editions) Zurich: Swiss Re Co.

Truett, D.B. and Truett, L.J. (1990) 'The demand for life insurance in Mexico and the United States: A comparative study', Journal of Risk and Insurance 57: 321-328.

UNESCO. UNESCO Statistical Yearbook (1994-2001) United Nations Educational, Scientific, and Cultural Organization, Paris, France.

Ward, D. and Zurbruegg, R. (2002) 'Law, politics and life insurance consumption in Asia', The Geneva Papers on Risk and Insurance - Issues and Practice 27(3): 395-412.

\section{About the Authors}

Dezhu Ye is an associate professor of Finance at Jinan University, Guangzhou, China. He obtained his Phd degree from the Sun Yat-Sen University, Guangzhou, China.

Zhian Chen is a lecturer of Finance at the School of Banking and Finance, the University of New South Wales, Sydney, Australia. He obtained his Phd in Finance from the same university.

Donghui Li is an associate professor of Finance at the School of Banking and Finance, the University of New South Wales, Sydney, Australia. He obtained his Phd in Finance from the same university.

Fariborz Moshirian is professor of Finance, School of Banking and Finance, the University of New South Wales, Sydney, Australia. He earned his Phd degree from the Monash University, Melbourne, Australia.

Timothy Wee is from the department of Equity Capital Markets, Citigroup Global Markets Asia Ltd, Hong Kong SAR. He has an honours degree from the School of Banking and Finance, the University of New South Wales. 